\title{
A potential prognostic indicator of fulminant hepatic failure: A valuable adjunct in preliver transplant assessment?
}

\author{
B YACYSHYN MD FRCPC, CM CHEUNG MD FRCPC, D GORDON MALKIN MSc MD, SC PAPPAS MD FRCPC
}

\begin{abstract}
B YACYSHYN, CM CHEUNG, DG MALKIN, SC PAPPAS. A potential prognostic indicator of fulminant hepatic failure: A valuable adjunct in preliver transplant assessment? Can J Gastroenterol 1994;8(5):308-312. The use of thyroid function tests as a method of monitoring patients with fulminant hepatic failure has been previously proposed. The use of these indices in two cases with fulminant hepatic failure are described. Both patients had simultaneous ingestion of hepatotoxic mushroom (amanita virosa). Their parallel clinical courses and recovery without liver transplantation is described, outlining the potential long term cost-savings achievable by such tests in the selection of patients for liver transplantation and the need for further study of these indices for this application.
\end{abstract}

Key Words: Fulminant hepatic failure, Hepatotoxin ingestion, Thyroid indices

\section{Indicateur potentiel du pronostic dans l'insuffisance hépatique} fulminante: complément utile dans l'évaluation préparatoire à la transplantation hépatique

RÉSUMÉ : Le recours aux épreuves de fonction thyroidienne comme méthode de surveillance des patients atteints d'insuffisance hépatique fulminante a déjà été proposé. L'utilisation de ces indices dans deux cas d'insuffisance hépatique fulminante est décrite ici. Les deux patients ont simultanément ingéré un champignon hépatotoxique (amanite). Leur évolution clinique parallèle et leur récupération sans transplantation hépatique sont décrites ici, soulignant les économies potentielles à long terme qu'il est possible de réaliser grâce à ces tests pour la sélection des patients en vue d'une transplantation hépatique et la nécessité de pousser la recherche sur ces indices dans des cas semblables.

Departments of Clinical Biochemistry and Medicine, Division of Gastroenterology, University of Alberta, Edmonton, Alberta; Sunnybrook Medical Centre, Toronto, Ontario; Department of

Transplantation, Methodist Hospital, Indianapolis, Indiana, USA

Correspondence and reprints: Dr Bruce Yacyshyn, 2E3.11 Walter Mackenzie Health

Sciences Centre, University of Alberta, Edmonton, Alberta T6G 2R7. Telephone (403)

492-5957, Fax (403) 492-3340

Received for publication December 14, 1993. Accepted April 27, 1994
$\mathrm{T}$ HE USE OF THYROID FUNCTION testing as a monitor of severe illness has been proposed in many diverse disease states (1). The measurement of the reverse triiodothyronine $\left(\mathrm{rT}_{3}\right)$ level has been shown to correlate with a poor prognosis (2). Although the measurement of thyroid function has been evaluated in cirrhosis and employed in the evaluation of liver transplantation candidates, the simultaneous evaluation of two patients (husband and wife) from the identical onset to the resolution of fulminant hepatic failure (FHF) using thyroid indices has not been reported (3). In these patients, the levels of $\mathrm{rT}_{3}$ and triiodothyronine $\left(\mathrm{T}_{3}\right)$, and $\mathrm{rT}_{3}: \mathrm{T}_{3}$ ratios have been reported to parallel closely their clinical course (2). These indices may provide an adjunct to current methods of assessing patients before liver transplantation and should be considered.

\section{CASE ONE}

A 42-year-old Caucasian female was admitted to hospital with acute abdominal pain, diarrhea and encephalopathy. No pertinent previous medical history was obtained from relatives; however, the patient and her husband 
TABLE 1

Liver and thyroid functions in fulminant hepatic failure for case 1

\begin{tabular}{|c|c|c|c|c|c|c|c|c|c|}
\hline Day & Clinical status & AST (IU/L) & ALT (IU/L) & $T_{3}$ & $\mathrm{rT}_{3}$ & $\mathrm{rT}_{3} \mathrm{~T}_{3}$ & $\begin{array}{l}\text { Prothrombin } \\
\text { time }(s)^{*}\end{array}$ & $\begin{array}{c}\text { Total } \\
\text { bilirubin }\end{array}$ & Creatinine \\
\hline & Normal & $10-55$ & $5-40$ & $1.2-3.4$ & $0.15-0.75$ & & - & - & - \\
\hline 1 & Ingestion of amanita virosa & & & & & & & & \\
\hline 5 & Fulminant hepatic failure & 2250 & $>1700$ & 0.8 & 4.77 & 6 & 62 & 140 & 80 \\
\hline 6 & Fulminant hepatic failure & 540 & $>1700$ & 0.7 & 4.01 & 5.7 & 27.9 & 260 & 90 \\
\hline 7 & Fulminant hepatic failure & 150 & $>1600$ & 0.7 & 3.54 & 5.1 & 27.0 & 150 & 80 \\
\hline 10 & Spontaneous bacterial peritonitis & 42 & 625 & 0.5 & 2.28 & 4.6 & 23.7 & 460 & 90 \\
\hline 11 & Spontaneous bacterial peritonitis & 35 & 450 & 0.7 & 1.48 & 2.1 & 24.1 & 350 & 90 \\
\hline 12 & Spontaneous bacterial peritonitis & 40 & 350 & 0.7 & 1.47 & 2.1 & 23 & 300 & 90 \\
\hline 13 & Recovery & 32 & 230 & 0.5 & 1.69 & 3.4 & - & - & - \\
\hline 17 & Recovery & 32 & 20 & 0.7 & 1.07 & 1.5 & 18 & 350 & 105 \\
\hline
\end{tabular}

"High International Standard Index reagent. ALT Alanine aminotransferase; AST Aspartate aminotransferase; $r T_{3}$ Reverse triiodothyronine $\left(3,3\right.$, ${ }^{2}$-triiodothyronine): $T_{3}$ Triiodothyronine

TABLE 2

Liver and thyroid functions in fulminant hepatic failure for case 2

\begin{tabular}{|c|c|c|c|c|c|c|c|c|c|}
\hline Day & Clinical status & AST (IU/L) & ALT (IU/L) & $T_{3}$ & $\mathrm{rT}_{3}$ & $\mathrm{rT}_{3} \mathrm{~T}_{3}$ & $\begin{array}{l}\text { Prothrombin } \\
\text { time }(s)^{*}\end{array}$ & $\begin{array}{c}\text { Total } \\
\text { bilirubin }\end{array}$ & Creatinine \\
\hline & Normal & $10-55$ & $5-40$ & $1.2-3.4$ & $0.15-0.75$ & & - & - & - \\
\hline 1 & Ingestion of amanita virosa & & & & & & 14.7 & - & - \\
\hline 5 & & - & - & 1.2 & 3.75 & 3.1 & 23.5 & 160 & 115 \\
\hline 6 & Fulminant hepatic failure & 400 & $>1700$ & 0.9 & 2.58 & 2.9 & 27.5 & 370 & 80 \\
\hline 9 & Fulminant hepatic failure & 200 & 700 & 0.8 & 1.71 & 2.1 & 18 & - & 105 \\
\hline 17 & Recovery & 70 & 50 & 1.2 & 0.52 & 0.4 & 12.8 & 240 & 85 \\
\hline 18 & Recovery & 90 & 46 & 1.1 & 0.5 & 0.5 & 12.8 & 190 & 95 \\
\hline 20 & Recovery & 80 & 48 & 1.5 & 0.43 & 0.3 & 12.8 & 150 & 80 \\
\hline
\end{tabular}

"High International Standard Index reagent. ALT Alanine aminotransferase; AST Aspartate aminotransferase; $r T_{3}$ Reverse triiodothyronine (3,3", $t$-triiodothyronine); $T_{3}$ Triiodothyronine

(case 2) had ingested wild mushrooms. The mushrooms had not been speciated, and were ingested because mushrooms picked from the same location had been eaten previously without undue effects. No other family member ingested the mushrooms. No medications had been taken by the patient. There was no history of illicit drug use, viral hepatitis, blood transfusions or recent travel. The patient was admitted to hospital with the diagnosis of FHF secondary to mushroom poisoning. In addition to standard supportive therapy, the patient was monitored with daily blood work including aspartate aminotransferase, alkaline phosphatase, alanine aminotransferase, gamma glutamyltranspeptidase, $\mathrm{T}_{3}$ (Abbott $\mathrm{T}_{3}$ RIA bead), $T_{4}$ (Abbott TDX fluores- cence polarization assay), $\mathrm{rT}_{3}$ (Serono RIA diagnostic kit ${ }^{125}$ I Radio-assay), T3 uptake (Abbott TDX fluorescence polarization assay), $\mathrm{T}_{3}$ immunoassay, thyroid-stimulating hormone (TSH) (Hybritech enzyme assay) and thyroid binding globulin (Corning Immo phase TBG ${ }^{125}$ I Radio-assay). Thyroid function on admission (day 1) were (normal range in brackets): $\mathrm{T}_{4}, 94$ $\mathrm{nmol} / \mathrm{L}$ (55 to 155$) ; \mathrm{T}_{3} \mathrm{U}, 0.57$ (0.75 to $1.55) ; \mathrm{T}_{3}, 0.8 \mathrm{nmol} / \mathrm{L}(1.2$ to 3.4$) ; \mathrm{TSH}$, $1.2 \mathrm{mIU} / \mathrm{L}(0.5$ to 6.0$)$; and testosterone-binding globulin, $15.3 \mathrm{mg} / \mathrm{L}$ (15 to 30). Bilirubin and creatinine were obtained from the patient's common chemistry panel. Prothrombin time was measured in seconds with a standard laboratory assay (Organon-Teknika).

During slow recovery, a sudden fever occurred, coincident with a small number of ascites, detected by shifting dullness and confirmed by ultrasound (Table 1). Diagnostic paracentesis revealed a leukocytosis of greater than 600 leukocytes/mL ascitic fluid. The patient was then started on intravenous antibiotics (ampicillin and gentamicin) and continued to recover. Identification of amanita virosa as the ingested mushroom was made by the patient after recovery, and confirmed by a mycologist after examining the area from which the mushrooms were picked.

\section{CASE TWO}

A 41-year-old Caucasian male was admitted to hospital after eating wild mushrooms five days previously. He developed FHF with hepatic encephalo- 


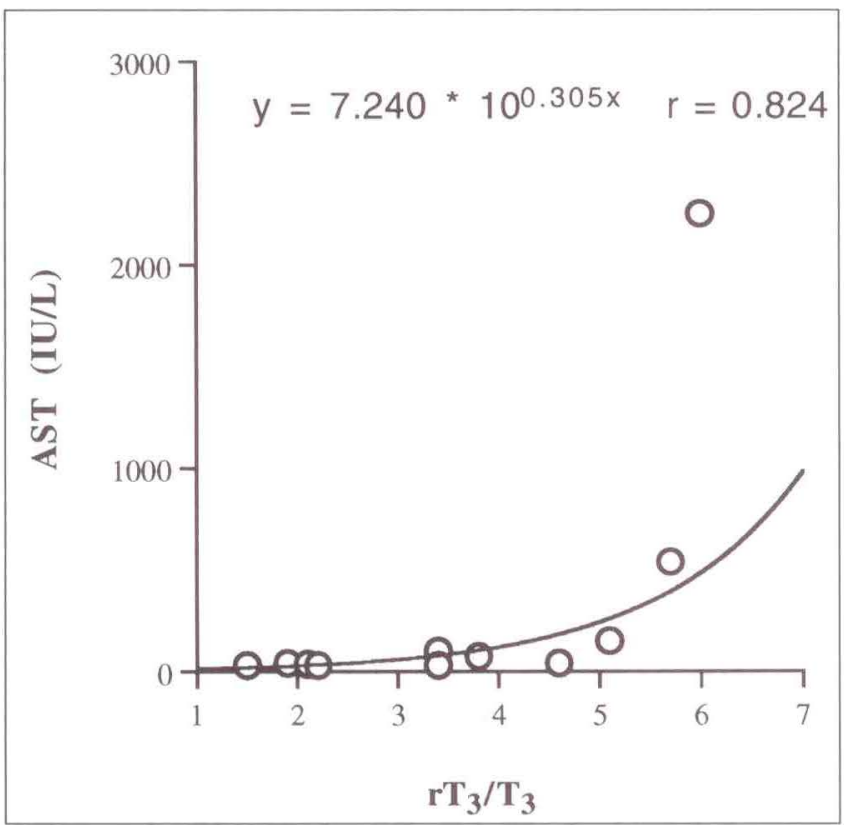

Figure 1) A close relationship between reverse triiodothyronine and triiodothyronine $\left(r \mathrm{~T}_{3} / \mathrm{T}_{3}\right)$ and aspartate aminotransferase (AST) is shown for case 1

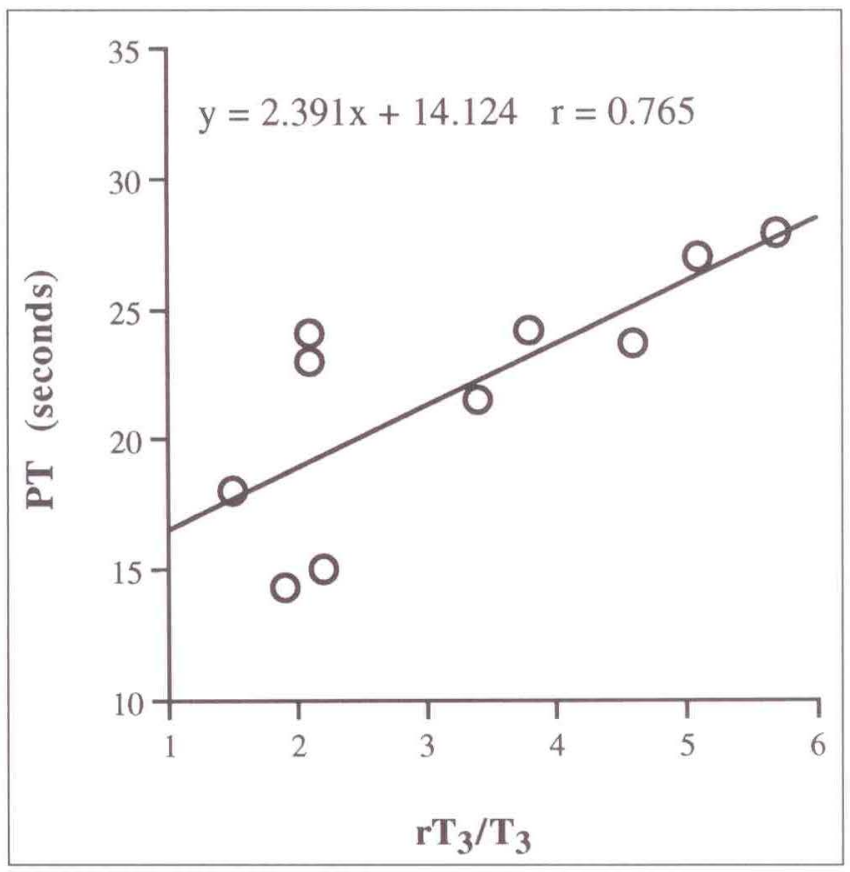

Figure 3) A relationship between prothrombin time (PT) and reverse triiodothyronine and triiodothyronine $\left(r T_{3} / T_{3}\right)$ was identified for case 1

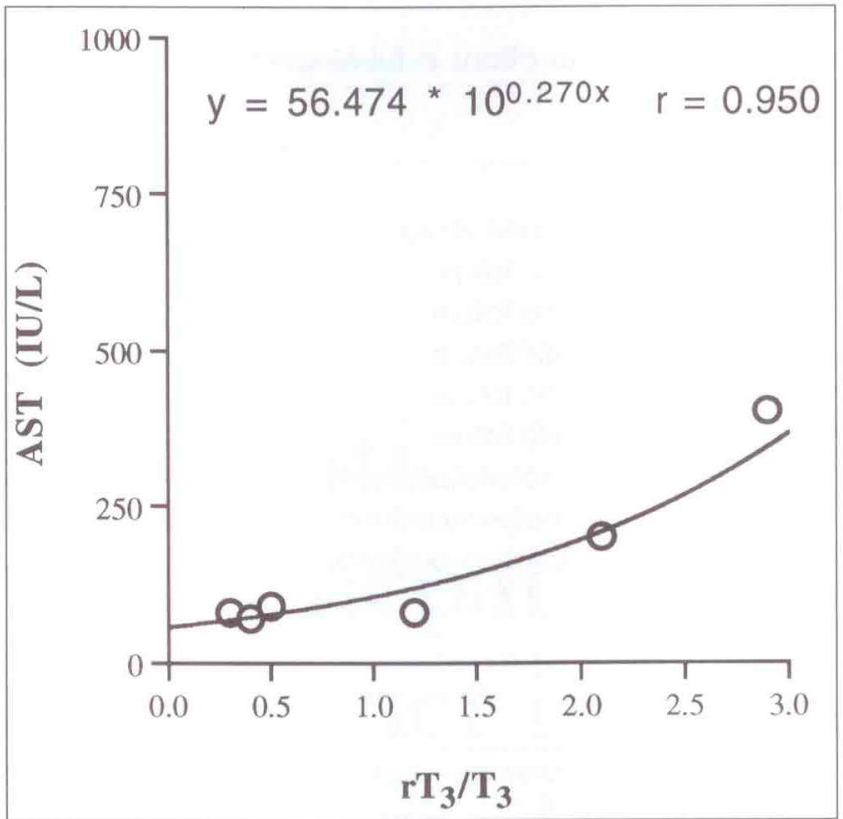

Figure 2) A close relationship between reverse triiodothyronine and triiodothyronine $\left(r T_{3} / T_{3}\right)$ and aspartate aminotransferase (AST) is shown for case 2

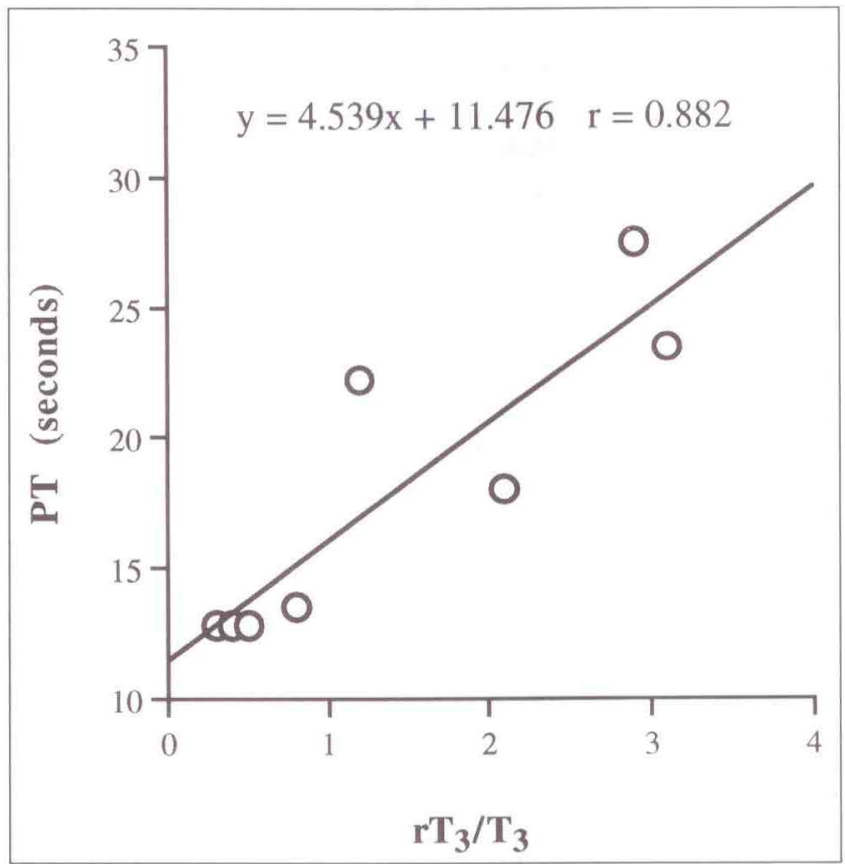

Figure 4) A relationship between prothrombin time (PT) and reverse triiodothyronine and triiodothyronine $\left(r T_{3} / T_{3}\right)$ was identified for case 2 pathy progressing to confusion and somnolence(stage II). Withsupportive therapy, profound hypoglycemia was controlled and gradual recovery of liver function occurred (Table 2). Thyroid function studies on admission were (normal range in brackets): $\mathrm{T}_{4}, 116$ $\mathrm{nmol} / \mathrm{L}$; thyroid uptake, $0.51 ; \mathrm{T}_{3}, 1.22$ $\mathrm{nmol} / \mathrm{L}$ (1.2 to 3.4 ); $\mathrm{TSH}$, less than 0.3 $\mathrm{mIU} / \mathrm{L}(0.5$ to 6.0$)$; and testosteronebinding globulin, $13.4 \mathrm{mg} / \mathrm{L}$ (15 to 30 ) (Table 2). Those values that were $a b$ normal on admission normalized during hepatic recovery. As with case 1, the ingested mushrooms were confirmed to be amanita virosa.

\section{DISCUSSION}

The need for objective biochemical indices to monitor patients with FHF before liver transplantation has been more pressing due to health care budgetary pressures (4). The long term expense in the care of liver transplant patients is not trivial, and the decision 
to perform a transplant therefore has long term considerations and should be buttressed by laboratory and clinical data best able to identify those patients in whom transplantation is necessary, although supportive care to allow native liver regeneration is the preferable management when possible.

O'Grady et al (5) reviewed 588 patients with acute hepatic failure using unvaried and multivarient analysis. They identified several criteria to determine prognosis of FHF to assist in determining when liver transplantation is indicated (5). These parameters include blood $\mathrm{pH}$, serum bilirubin, prothrombin time, serum creatinine, age and degree of encephalopathy among others.

Hepatotoxin ingestion resulting in FHF is frequently managed by liver transplantation. Of these, certain poisonous mushrooms have long been known to contain hepatotoxins, and identification of their specific toxins have provided models of hepatotoxicity $(6,7)$. The ingestion of amanita virosa by these patients inadvertently provided an opportunity to evaluate serial thyroid function testing in two patients with acute FHF.

A direct primary action of toxic mushroom ingestion on the thyroid gland is not described. The liver has been identified as an important regulator of thyroid hormone homeostasis (812). Identification of specific patterns of thyroid hormone abnormalities has been described for different hepatic diseases. For instance, serum $T_{3}$ has been proposed as an index of the severity of alcoholic liver disease (13). Several tissues convert $\mathrm{T}_{4}$ to $\mathrm{T}_{3}$ (the active hor-

ACKNOWLEDGEMENTS: The valuable assistance of Dr Jody Ginsberg in revising this manuscript is highly appreciated. Appreciation of manuscript preparation is expressed to Wendy McEachern.

\section{REFERENCES}

1. Zaloga GP, Ghernow B. Thyroid function in acute illness. In: Geelhoed GI, Chernow B, eds. Endocrine Aspects of Acute Illness. New York: Churchill Livingstone, 1985:67-96.

2. Kabadi UM, Premachandra BN. Serum $T_{3}$ and reverse $T_{3}$ levels in hepatic mone) and the biologically inert $\mathrm{rT}_{3}$ $\left(3,3^{\prime}, t^{\prime}\right.$-triiodothyronine). However, degradation of $\mathrm{rT}_{3}$ and $\mathrm{T}_{3}$ is catalyzed by the enzyme iodothyronine $5^{\prime}$-deiodinase located primarily in liver and kidney (14). Severe forms of hepatic disease with a deficiency of this enzyme result in a reduction in plasma $T_{3}$ levels and an increase in $\mathrm{rT}_{3}$ levels in association with a normal TSH level. This pattern of thyroid indices is known as the 'low T3 syndrome' and is prognostically useful in alcoholic liver disease and in assessing potential liver transplant recipients (3,13-15). Furthermore, replacement thyroid hormone therapy has not been shown to benefit euthyroid-sick patients (16).

The prognostic use of $\mathrm{rT}_{3}$ in patients with hepatocellular disease has been described with one study attributing an 11-fold increased risk of death to an $\mathrm{rT}_{3}$ value greater than $0.590 \mathrm{ng} / \mathrm{mL}$ which is equal to $0.761 \mathrm{nmol} / \mathrm{L}$ (3). As shown in case 1 , the elevation of $\mathrm{rT}_{3}$ corresponded to clinical deterioration with development of spontaneous bacterial peritonitis on day 10 with this measurement decreasing progressively with clinical improvement (Table 1). This correlation of $\mathrm{rT}_{3}: \mathrm{T}_{3}$ to hepatocellular damage corresponds with the aspartate aminotransferase levels of each patient (Figures 1,2). Similarly, the more serious clinical course was experienced by case 1 who consistently had a higher $\mathrm{rT}_{3}: \mathrm{T}_{3}$ ratio than case 2 (Table 1).

The depressed thyroid hormone level associated with poor prognosis in severe liver disease was at first shown in our patients, but returned to normal as both patients returned to euthyroid

cirrhosis: Relation to hepatocellular damage and normalization on improvement in liver dysfunction. Am J Gastroenterol 1983;78:750-5.

3. Van Thiel DH, Udani M, Schade RR, et al. Prognostic value of thyroid hormone levels in patients evaluated for liver transplantation. Hepatology 1985;5:862-6.

4. Fingerote RJ, Bain VG. Fulminant hepatic failure. Am J Gastroenterol 1993;88:1000-10.

5. O'Grady JG, Alexander GJM, Hayllar KM, Williams R. Early indicators of prognosis in fulminant hepatic status (Tables 1,2) (13). Furthermore, a good relationship was shown between $\mathrm{rT}_{3}: \mathrm{T}_{3}$ and prothrombin time (Figures 3,4). This finding is consistent with that from a group at Oxford - identification of prothrombin time as a prognostic factor in FHF (5).

With acute forms of hepatitis, an increase in serum thyroxine and thyroxine-binding globulin has been shown. These increases have been postulated to be secondary to increased thyroxine-binding globulin in regenerating hepatocytes, the release of thyroxine-binding globulin by damaged hepatocytes or decreased thyroxinebinding globulin clearance (17-19).

As these two patients illustrate, the level of $r T_{3}$ and $T_{3}$, and the $r T_{3}: T_{3}$ ratio correlate well with the clinical status of FHF due to hepatotoxic mushroom ingestion. These patients exhibit a high $\mathrm{rT}_{3}: \mathrm{T}_{3}$ ratio, reflecting the clinical course of FHF. Overall, this pattern is consistent with the low $\mathrm{T}_{3}$ syndrome; however, the low TSH found in case 2 is likely due to the severe physiological stress of FHF. The use of thyroid indices as adjunctive indicators of hepatic function in FHF allowed for prediction of clinical deterioration before the development of spontaneous bacterial peritonitis in one patient, and subsequently paralleled their eventual complete recovery. Such measurements are useful in the assessment of hepatic disease in view of the liver's key role in thyroid hormone metabolism and homeostasis. Such information should be studied in other etiologies of FHF and may be of valuable assistance in treating a patient in whom the need for liver transplantation is borderline.

failure. Gastroenterology 1989;97:439-45.

6. Mack RB. Termination with extreme prejudice. N C Med J 1984;8:521-2.

7. Hanrahan JP, Gordon MA. Mushroom poisoning: Case reports and a review of therapy. JAMA 1984;251:1057-61.

8. Klachko DM, Johnson ER. The liver and circulating thyroid hormones. J Clin Gastroenterol 1983;5:465-71

9. Normura S, Pittman CS, Chambers JB Jr, et al. Reduced peripheral conversion of thyroxine to triiodothyroxine in patients with 
hepatic cirrhosis. J Clin Invest 1975;56:643-52.

10. McConnon J, Row VV, Volpe R. The influence of liver damage in man on the distribution and disposal rates of thyroxine and triiodothyroxine. J Clin Endocrinol Metab 1972;34:144-51.

11. Chopra IJ, Solomon PH, Chopra U, et al. Alterations in circulating thyroid hormones and thyrotropin in hepatic cirrhosis: Evidence for euthyroidism despite subnormal serum triiodothyroxine. J Clin Endocrinol Metab 1979;39:501-11.

12. Inada M, Sterling K. Thyroxine turnover and transport in Laennec's cirrhosis of the liver. J Clin Invest 1967;46:1275-82.

13. Israel Y, Walfish G, Orrego H. Thyroid hormone in alcoholic liver disease. Effect of treatment with 6-npropylthiouracil. Gastroenterology 1979;76:116-22.

14. Hepner GW, Chopra IJ. Serum thyroid hormone levels in patients with liver disease. Arch Intern Med 1979;139:1117-20.

15. Walfish PG, Orrego H, Israel Y, et al. Serum triiodothyroxine and other clinical and laboratory indices of alcoholic liver disease. Ann Intern Med 1979;91:13-6.

16. Brent GA, Hershman JM. Thyroxine therapy in patients with severe nonthyroidal illnesses and low serum thyroxine concentration. J Clin Endocrinol Metab 1986;63:1-8.

17. Ross DS, Daniels GH, Dienstage JL, Ridgway EC. Elevated thyroxine levels due to increased thyroxine-binding globulin in acute hepatitis. Am J Med 1983; 74:564-9.

18. Shigemasa C, Tanaka T, Mitani Y, et al. Are increases in thyroxinebinding globulin in patients with acute hepatitis ascribable to synthesis by regenerating hepatocytes? Clin Chem 1988;34:776-80.

19. Hegedus L. Thyroid gland function during and after acute hepatitis infection. Metabolism 1986;35:495-8. 


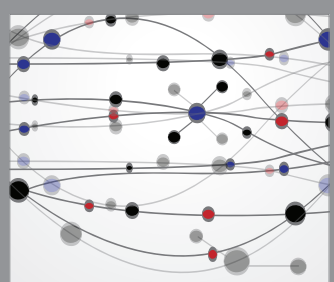

The Scientific World Journal
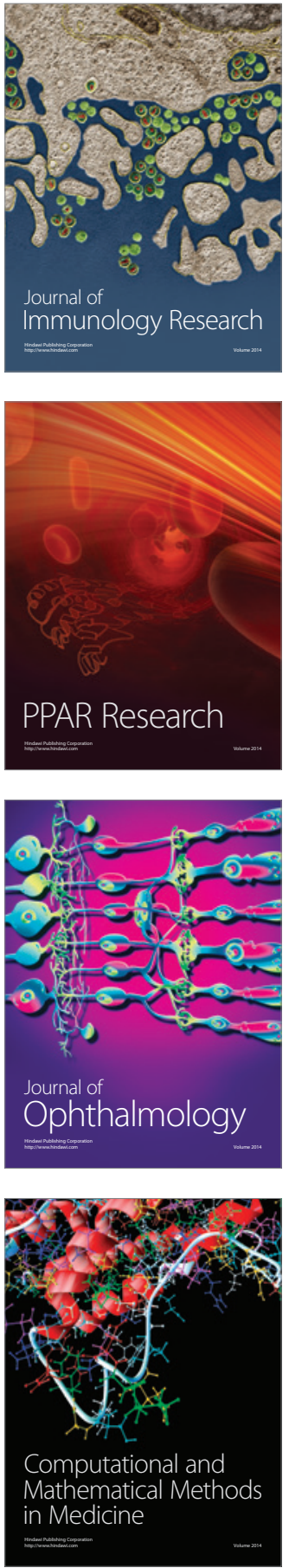

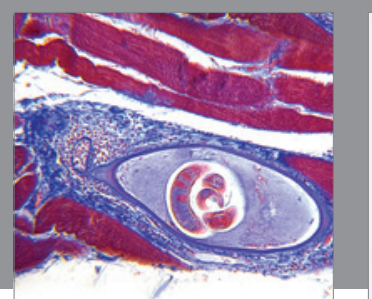

Gastroenterology Research and Practice

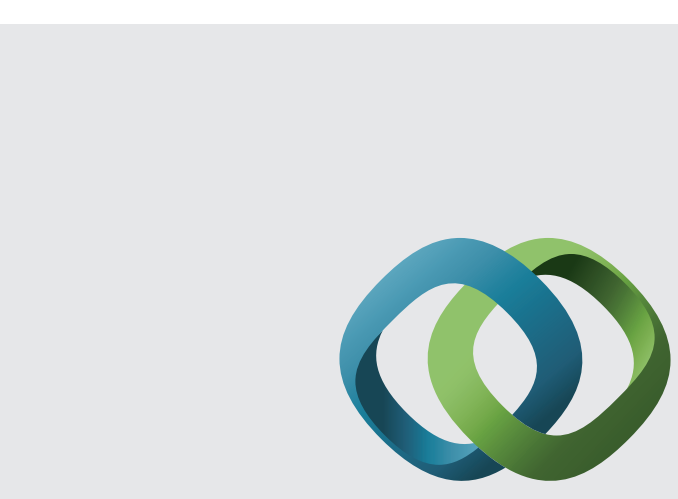

\section{Hindawi}

Submit your manuscripts at

http://www.hindawi.com
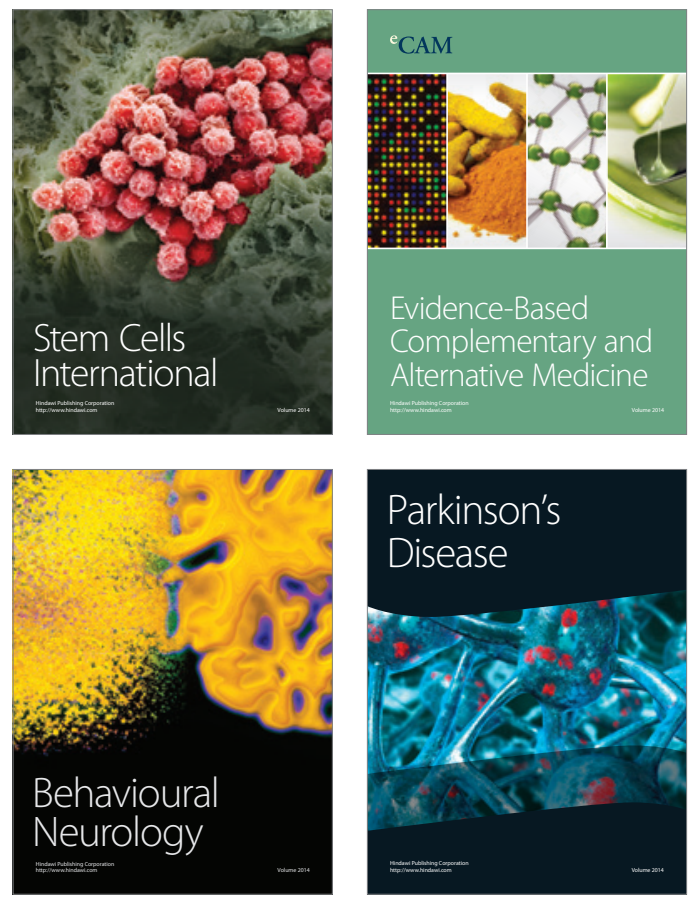
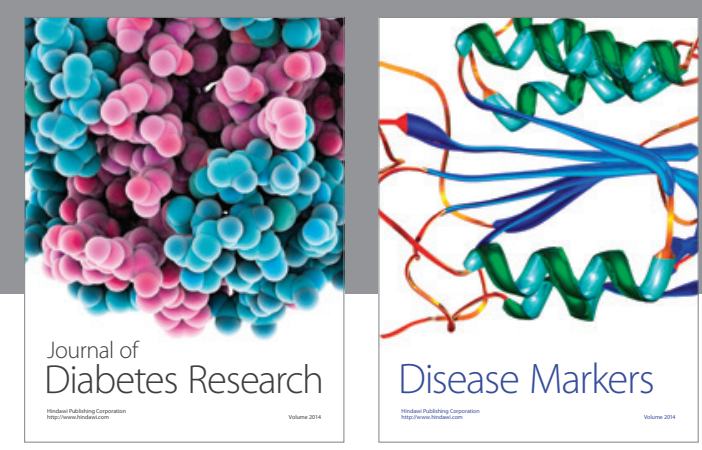

Disease Markers
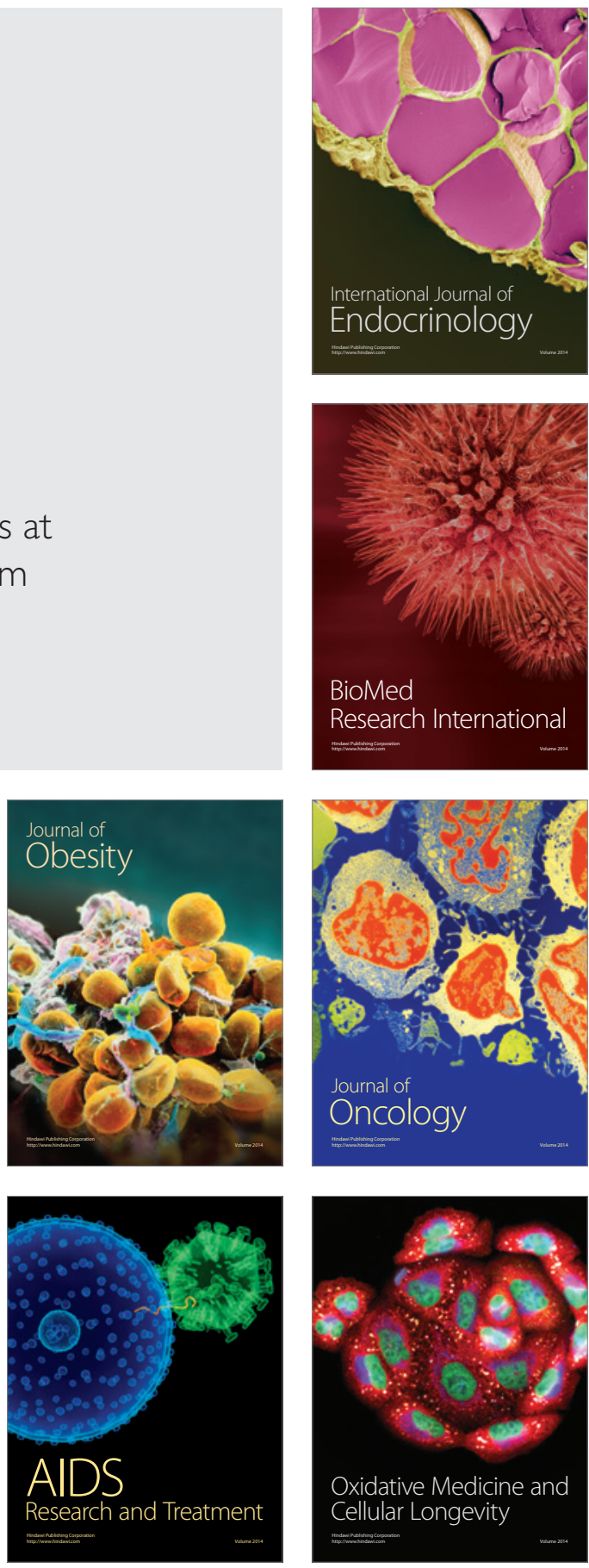